\title{
EFFECT OF HIGH TEMPERATURE ON MECHANICAL PROPERTIES OF CONCRETE CONTAINING ADMIXTURES
}

\author{
AHMAD,A.H. (Professor) \\ Abdulkareem,O.M
}

Civil Engineering Dept. University of Mosul

\begin{abstract}
This research work includes an experimental investigation to study the effect of high temperatures on the mechanical properties of concrete containing admixtures. A comparative study was conducted on concrete mixes, reference mix without an additive and that with an admixture. Concrete was exposed to three levels of high temperatures $(200,400,600)^{\circ} \mathrm{C}$, for a duration of one hour, without any imposed load during the heating. Five types of admixtures were used, superplasticizer, plasticizer, retarder and water reducing admixture, an accelerator and an air entraining admixture.

Mechanical properties of concrete were studied at different high temperatures, including: compressive strength, splitting tensile strength, modulus of elasticity and ultimate strain. Test results showed a reduction in the studied properties by different rates for different additives and for each temperature, the decrease was very limited at temperature up to $\left(200^{\circ} \mathrm{C}\right)$ but was clear at $(400,600)^{\circ} \mathrm{C}$.
\end{abstract}

Key words: concrete containing admixtures, high temperatures, mechanical properties.

$$
\begin{aligned}
& \text { تأثير ألحرارة ألعالية على ألخصائص ألميكاتيكية للخرسانة الحاوية على المضافات }
\end{aligned}
$$

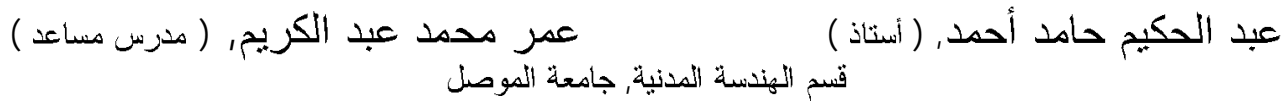

\section{الخلاصة}

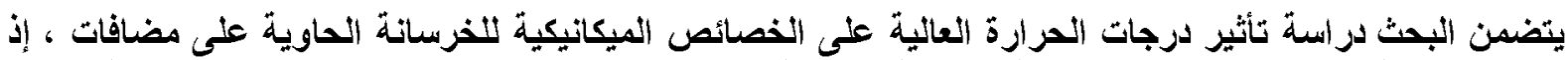

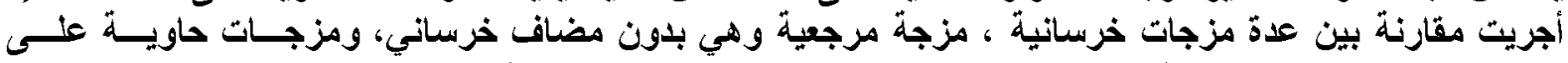

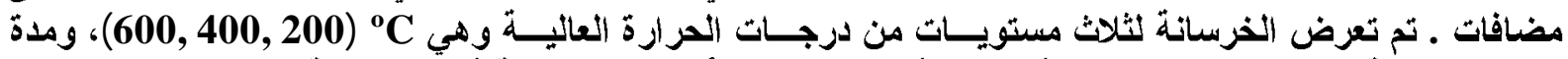

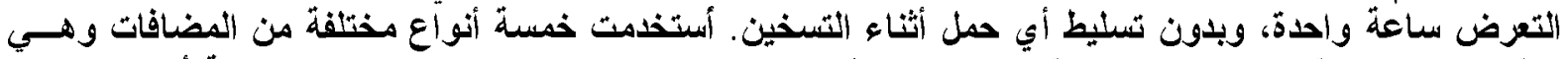

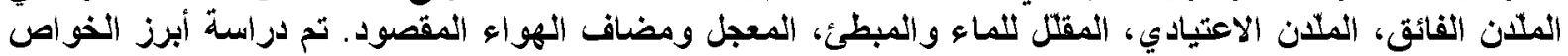

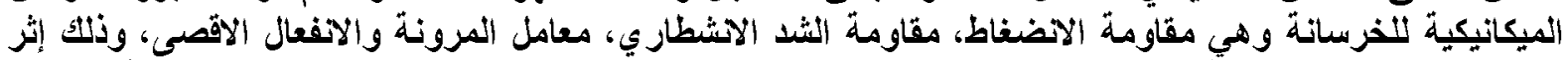

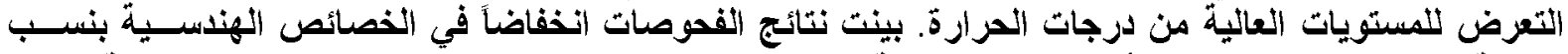

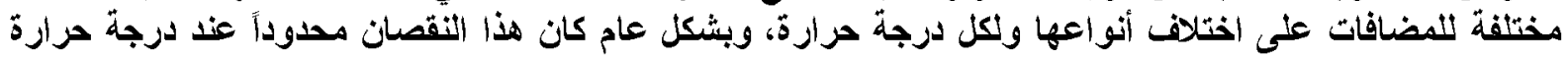
(200C) 


\section{$\begin{array}{llll}\text { Al-Rafidain Engineering } & \text { Vol.18 } & \text { No.4 } & \text { August } 2010\end{array}$}

\section{INTRODUCTION}

Concrete acts as an unflammable construction material; however most of its mechanical properties are changeable due to chemical and physical changes that may occur due to high temperatures effect, such as concrete strength, modulus of elasticity etc., although these effects occur in different manners, this causing a disadvantage in the properties of the building materials (concrete and steel reinforcement) which may be controlled by several means such as : modification of the relative codes of practice. Therefore; this research work aims to evaluate properties of the concrete containing (superplasticizer, normal plasticizer, retarder and water reducing, accelerator and air entraining admixture) when subjected to high temperatures of $(200,400,600)^{\circ} \mathrm{C}$.

In (2002) Tolentino et al. [1] analyzed the residual performance of Portland cement concretes heat-treated at $(600){ }^{\circ} \mathrm{C}$ after cooling down to room temperature. Concretes with characteristic compressive strength at (28) days of (45) MPa and of (60) MPa were studied. The heat-treatment was carried out without any imposed load. Researchers measured the residual compressive strength and modulus of elasticity. The geometry of the structure was described by mercury intrusion porosimetry and nitrogen sorption tests. They observed a decrease of residual compressive strength and modulus of elasticity, with the raise of heattreatment temperature, as a result of heat-induced material degradation. The results also indicated that the microstructural damage increased steadily with increasing temperature. Based on the results of this experimental work they concluded that residual mechanical properties of concrete are dependent of their original non heat-treated values.

In (2004) Yüzer et al. [2], carried out a study on the effects of fire and extinguishing on the properties of concrete, mortars with and without silica fume were exposed to different temperatures, such as $\left(100,200,300,600,900\right.$ and 1200) ${ }^{\circ} \mathrm{C}$ and cooled slowly in the air and fast in water in two groups. Flexural and compressive strength tests were performed on the samples which were cooled up to room temperature and changes in compressive strength in color were determined by Munsell Color System. High temperature has caused damages in decrease in mechanical strengths at $(600){ }^{\circ} \mathrm{C}$. Researchers observed that the changes in color's hue component and the compressive strength have similarities. Test results show that residual color changes in mortar can give an idea about the effect of high temperatures on mechanical properties of mortar during a fire.

In (2005) Savva et al. [3], have studied the influence of high temperatures on concrete mechanical properties and properties that affect the measurement by non destructive methods (rebound hammer and pulse velocity) of concrete containing various levels $(10 \%$ and $30 \%)$ of pozzolanic materials. Three types of Pozzolans, one natural pozzolan and two lignite fly ashes (one of low and the other of high lime content) were used for cement replacement. Two series of mixtures were prepared using limestone and siliceous aggregates. The $\mathrm{W} / \mathrm{b}$ and the cementitius material content were maintained constant for all the mixtures. Concrete specimens were tested at $(100,300,600$ and 750$){ }^{\circ} \mathrm{C}$ for $2 \mathrm{~h}$ without any imposed load, and under the same heating regime. At the age of (3) years, tests of compressive strength, modulus of elasticity, rebound hammer and pulse velocity were come out. Results indicate that the residual properties of concrete as well as rebound and pulse velocity versus heating temperatures are established. The above results are evaluated to establish a direct relationship between non-destructive measurements and compressive strength of concrete exposed to fire. 


\section{RESEARCH SIGNIFICANCE}

The aim of this investigation is to study the influence of exposing to high temperatures on some mechanical properties of concrete containing admixtures. The Iraqi standard specifications have not refer to effect of temperature on concrete containing admixtures. The British specifications and (ASTM) discuss the effect of temperature on concrete and the effect of admixtures on concrete independent each other, but had not taken the effect of temperature on concrete containing admixtures, therefore necessity of such study.

It is expected that each admixture added to concrete has a different effect on the mechanical properties, under the influence of high temperatures.

\section{EXPERIMENTAL PROGRAM \\ 3.1. Materials \\ Cement:}

Locally available ordinary portland cement produced in "Badoosh cement factory" according to the Iraqi standard specification (IQS, No.5, 1984) was used throughout the research work. The chemical and mineralogical analysis of the cement is shown in table (1).

Table (1): Chemical and Mineralogical Analysis of Cement

\begin{tabular}{|c|c|c|}
\hline Chemical Composition & $($ IQS: $5 / 1984)(\%)$ & ASTM C150 (\%) \\
\hline $\mathrm{CaO}$ & 62.76 & \\
\hline $\mathrm{SiO}_{2}$ & 21.50 & \\
\hline $\mathrm{Al}_{2} \mathrm{O}_{3}$ & 6.20 & \\
\hline $\mathrm{MgO} \mathrm{Fe} \mathrm{O}_{3}$ & $2.75(5.00$ maximum) & 6.00 maximum \\
\hline $\mathrm{SO}_{3}$ & 3.25 & \\
\hline Mineralogical Composition & (IQS: 5/1984) (\%) & ASTM C150 (\%) \\
\hline $\mathrm{C}_{3} \mathrm{~S}$ & 46.24 & \\
\hline $\mathrm{C}_{2} \mathrm{~S}$ & 27.18 & \\
\hline $\mathrm{C}_{2} \mathrm{~A}$ & $11.56(5.00$ minimum) & \\
\hline $\mathrm{C}_{4} \mathrm{AF}$ & 7.61 & \\
\hline & & \\
\hline
\end{tabular}

Water:

Ordinary drinking (tap) water from Mosul area was used in all concrete mixes of this study.

\section{Fine aggregate:}

River aggregate obtained from "Al-Khazir" near by Mosul area was used with fineness modulus of (1.84) and a gradation compatible to the Iraqi standard specification (IQS, No.5, 1980). The characteristics of fine aggregate is shown in table (2).

\section{Coarse aggregate:}

River gravel available in the suburbs of Mosul area with a maximum aggregate size of $(20 \mathrm{~mm})$ was used; compatible to the Iraqi standard specification (IQS, No.5, 1980). The characteristics of coarse aggregate is shown in table (2).

Table (2): Properties of Fine and Coarse Aggregate

\begin{tabular}{|c|c|c|c|}
\hline \multirow{2}{*}{ Aggregate Type } & \multicolumn{2}{|c|}{ Specific Gravity } & \multirow{2}{*}{$\%$ Absorption } \\
\cline { 2 - 3 } & SSD & Oven Dry & \\
\hline Fine & 2.63 & 2.59 & 1.5 \\
\hline Coarse & 2.65 & 2.63 & 0.8 \\
\hline
\end{tabular}




\section{2. Fresh Concrete}

The concrete mix is prepared as follows:

1) Design of the mix :

Mix was designed according to British method (Department of Environment (DOE)), with a specified compressive strength of (30 MPa) at (28) days and a slump of $(100 \mathrm{~mm})$ on the basis that both aggregate (fine and coarse) were in a saturated surface dry state. The mixing proportions are (1:1.14:3.07/0.54) (cement: fine aggregate: coarse aggregate : $\mathrm{w} / \mathrm{b}=\mathrm{w} / \mathrm{c}$ ratio), with a cement content of $\left(415 \mathrm{~kg} / \mathrm{m}^{3}\right)$. The additives used were in an amount as recommended by the manufacturer and as shown in table(3):

Table (3): Dosage of Used Admixtures

\begin{tabular}{|c|c|c|c|c|c|}
\hline Type of Additive & $\begin{array}{c}\text { Super } \\
\text { plasticizer } \\
\text { (Rheobuild } \\
800)\end{array}$ & $\begin{array}{c}\text { Plasticizer } \\
\text { (Pozzolith } \\
322 \mathrm{~N})\end{array}$ & $\begin{array}{c}\text { Retarding } \\
\text { and Water } \\
\text { Reducing } \\
\text { (Pozzolith } \\
\text { 100Ri) }\end{array}$ & $\begin{array}{c}\text { Accelerator } \\
\text { (Colloidal } \\
\text { Silicates) }\end{array}$ & $\begin{array}{c}\text { Air } \\
\text { (Polyraining } \\
32 / 1 \\
+ \text { Isorex } \\
\text { R 310/1) }\end{array}$ \\
\hline $\begin{array}{c}\text { Dosage } \\
\text { (mls/100kg of } \\
\text { cement) }\end{array}$ & 1000 & 327.5 & 195 & 437.5 & 1666.7 \\
\hline
\end{tabular}

2) Casting of the specimens:

After the concrete had been prepared according to the design outcome; (100x100x100) mm cubes and (100x200) mm cylinders specimens were cast three specimens for each test, (72) specimens were be tested at the age of (28) days.

The specimens were cured in water for (28) days at room temperature $(20 \pm 1)^{\circ} \mathrm{C}$. At the end of the curing period, the specimens were left to dry in the air for $(2 \mathrm{hrs})$ prior to heating.

\section{3. Concrete Heating and Cooling Process}

The concrete specimens were heated to different levels of high temperatures; using an electrical furnace with a maximum temperature of $\left(1200^{\circ} \mathrm{C}\right)$. The furnace is consisted of wide chamber of a double metal containing auto-control thermal probes; with built in thermocouples. The temperature of the furnace increases by an average value of $\left(5^{\circ} \mathrm{C} / \mathrm{min}\right)$ at its primary stage up to $\left(200^{\circ} \mathrm{C}\right)$, becoming faster to about $\left(10^{\circ} \mathrm{C} / \mathrm{min}\right)$ at the required temperature. The concrete specimens were then placed inside the furnace for one hour at a constant temperature; after that the specimens were left for $(24 \mathrm{hrs})$ to be air cooled.

\section{4. Tested Parameters}

The following mechanical properties were investigated on heat-treated specimens:

1) Compressive strength test was carried out on $(100 \times 100 \times 100) \mathrm{mm}$ cubes according to British standard specification (BS1881:Part116: 1983).

2) Splitting tensile strength test was performed on cylindrical specimens $(100 \times 200) \mathrm{mm}$ according to (ASTM C496-71).

3) An electrical strain gauge (YL-10) of $(10 \mathrm{~mm})$ length was used to measure the strain changes in a concrete cube due to changes of stress up to ultimate strength. The strain was measured by a digital strain meter (TDS-301). Compressive stress-strain relation is then presented. 


\section{RESULTS AND DISCUSSION}

\subsection{Compressive Strength:}

Figure (1) shows the change of the residual compressive strength in concrete mixes at an age of (28) days during the temperatures rise.

In general, the compressive strength of different concrete mixes is decreased by various proportions as a result of exposure to high temperatures. For reference concrete mix at (28) days, the residual compressive strengths are about $(95 \%, 83 \%, 42 \%)$ at temperature of $(200,400,600){ }^{\circ} \mathrm{C}$ respectively. The residual stresses for concrete containing additives ranged from $(75 \%-94 \%)$ at a temperature of $\left(200{ }^{\circ} \mathrm{C}\right)$. The highest stress was that for concrete containing the plasticizer; while the mix containing air entraining additive maintained the lowest proportion $(75 \%)$. At a temperature of $\left(400^{\circ} \mathrm{C}\right)$, the residual compressive strength for concrete containing additives ranged between (59\%-88\%). Retarding and water reducing additive maintained the highest proportion of compressive strength $(88 \%)$. The accelerating additive maintained the lowest proportion of $(59 \%)$. At a temperature of $\left(600{ }^{\circ} \mathrm{C}\right)$ these proportions ranged between $(31 \%-50 \%)$. Concrete containing retarding and water reducing additive is maintaining a highest residual strength, about (50\%); whereas the lowest residual strength $(31 \%)$ is for that containing superplasticizer.

Test results show different losses in compressive strength at different temperatures and different additives. The obvious loss begins at temperature after $\left(300{ }^{\circ} \mathrm{C}\right)$ which represents the critical temperature at which the strength loss would be rapid and continues with temperature rise [4]. It is well-known that the concrete consists of discrete aggregate dispersed in a continuous cement paste matrix, and that the transition zone between cement paste matrix and the aggregate is considered to be a critical zone and evidently affects concrete performance exposed to high temperatures[1]. It is noticed that changes occurring in this zone is responsible for the loss of compressive strength through the pore structure coarse for the cement paste structure and aggregate, as a result of non -thermo identification between the cement paste and the aggregate which consequently causes a bond failure between the cement paste and aggregate surface; in addition to the effect of the vaporized water pressure during the heating process [1], the chemical changes occurring in this zone represented by the loss of free moisture, the increase in calcium content $(\mathrm{C}-\mathrm{S}-\mathrm{H})$ and from elongation of calcium hydroxide crystals spreading tightly in cement paste at temperatures rise and so on[5]. Besides other chemical and physical changes such as shrinkage occurring in cement paste or mortar and aggregate expansion which leads to the appearance of microcracks in the concrete [6] .

It can be noticed that all concrete mixes containing admixtures, except that containing retarding and water reducing additive, tend to loose higher percentage of its compressive strength at a heat- treatment compared to normal concrete.

\subsection{Splitting Tensile Strength:}

Figure (2) shows the change in the rate of residual splitting tensile strength in concrete mixes at the age of (28) days with temperatures. It can be observed that the rate of the residual splitting tensile strength for the reference concrete mix reached $(95 \%)$ at a temperature of $\left(200{ }^{\circ} \mathrm{C}\right)$, reduced to $(71 \%)$ at a temperature of $\left(400{ }^{\circ} \mathrm{C}\right)$, and became $(47 \%)$ when temperature rise to $\left(600^{\circ} \mathrm{C}\right)$.

The residual splitting tensile strength in concrete mixes containing additives ranged between (75\%-94\%) at temperature of $\left(200{ }^{\circ} \mathrm{C}\right)$. The mix containing superplasticizer maintaining a higher proportion of this strength compared to the reference mix (94\%); whereas the mix containing the accelerating additive maintaining the least proportion $(75 \%)$. 


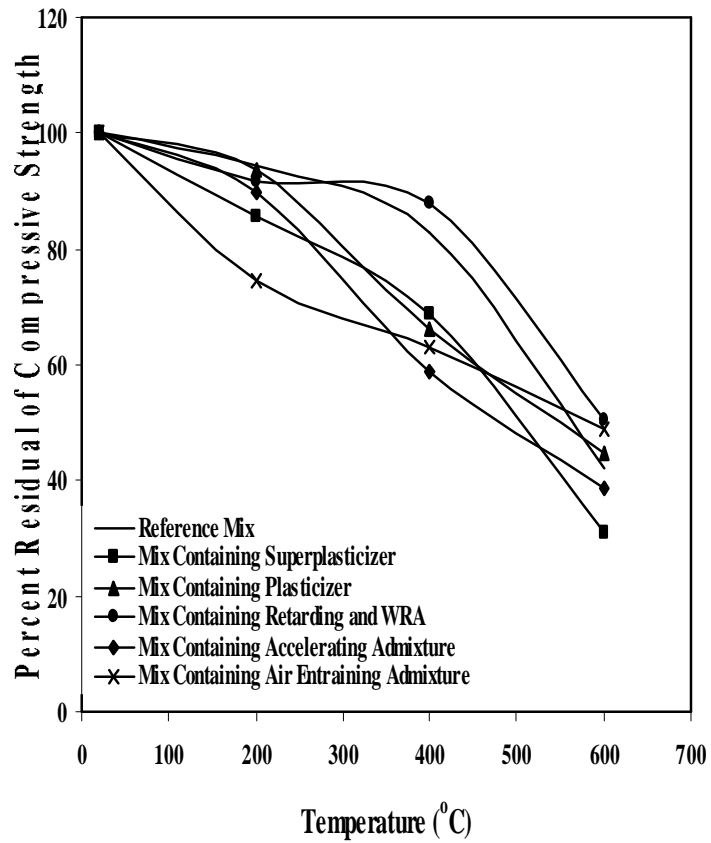

Figure (1): Change in the rate of the residual compressive strength in concrete mixes at (28) days with the temps rise.

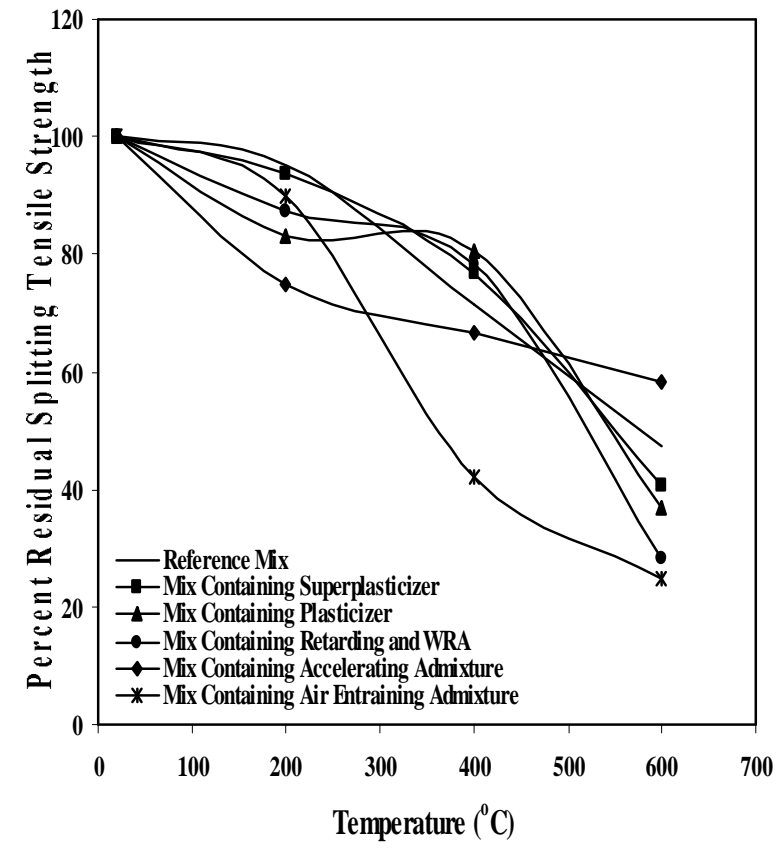

Figure (2): Change in the rate of residual splitting tensile strength in concrete mixes at (28) days with the rise of temp.

At temperature of $\left(400{ }^{\circ} \mathrm{C}\right)$ the residual splitting tensile strength for concrete mixes containing additives ranged between (42\%-80\%). The highest residual rate of splitting tensile strength is for concrete containing plasticizer, compared with the reference mix that is about $(80 \%)$, and the least value $(42 \%)$ is for the mix containing air entraining additive.

At temperature of $\left(600{ }^{\circ} \mathrm{C}\right)$ the residual splitting tensile strength ranged between (25\%-85\%), the mix containing an accelerating additive maintained the higher rate, reached $(58 \%)$, whereas the mix containing an air entraining additive maintained the least ratio $(25 \%)$ of this strength. It has been found that the splitting tensile strength is more sensitive to heatexposure than the compressive strength, for example, the rates of residual compressive strength in the mix containing superplasticizer are $(86 \%, 69 \%, 31 \%)$, while the rates of residual splitting tensile strength in the same mix are $(94 \%, 77 \%, 41 \%)$ at $(200,400,600){ }^{\circ} \mathrm{C}$ respectively.

\subsection{Modulus of Elasticity:}

The secant elastic modulus of the different mixes was calculated from the stress-strain relation produced previously according to (ACI Code) [7].

Figure (3) shows the variation of the residual secant elastic modulus with high temperatures. Figure (4) shows that the residual percent of the reference mix at $\left(200{ }^{\circ} \mathrm{C}\right)$ equals $(57 \%)$ of elastic modulus at its initial value, then changed to $(30 \%)$ at a temperature of $\left(400{ }^{\circ} \mathrm{C}\right)$ and $(26 \%)$ at $\left(600^{\circ} \mathrm{C}\right)$. 


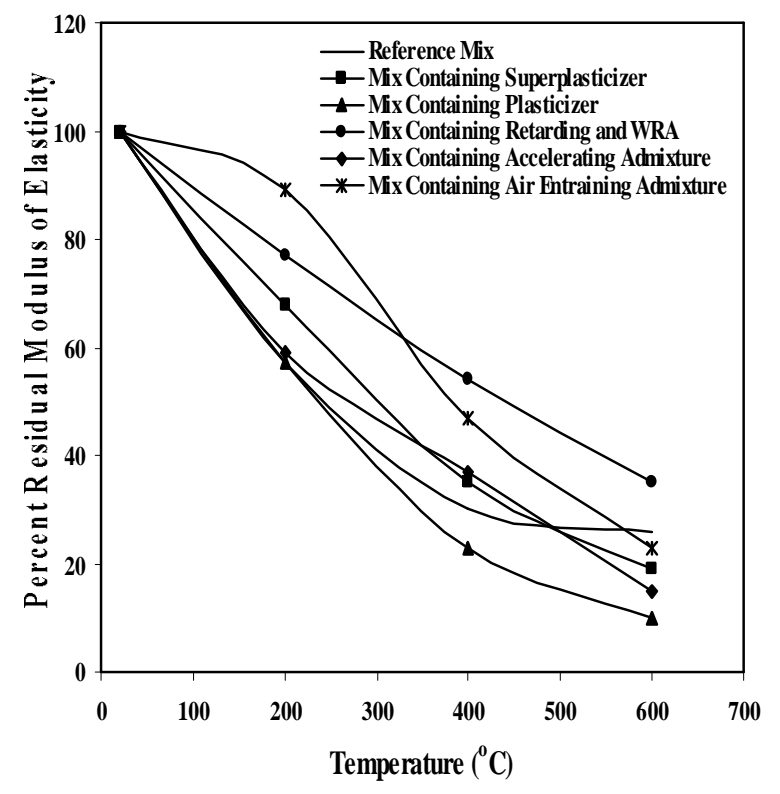

Figure (3): The variation proportion of residual elastic modulus of concrete mixes at an age (28) days with the temperature rise.

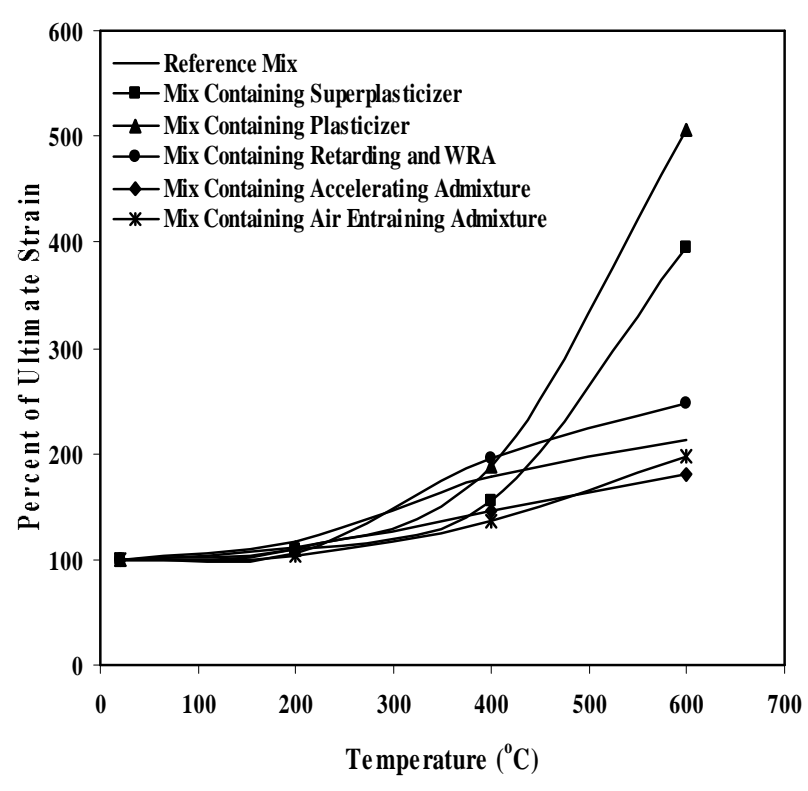

Figure (4): The extent of ultimate strain variability for concrete mixes at an age of (28) days with the rise of the temperatures.

On the other hand, the values ranged between (10\%-89\%) for the mixes containing additives at a temperature of $\left(200^{\circ} \mathrm{C}\right)$. The mix containing air entraining additive maintained the highest proportion of (89\%) compared to the reference mix; whereas the mix containing plasticizer additive maintained the least value $(10 \%)$. At a temperature of $\left(400{ }^{\circ} \mathrm{C}\right)$, the residual elastic modulus ranged between $(27 \%-54 \%)$ for concrete containing additives. The mix containing retarding and water reducing admixture maintained the highest rate of $(54 \%)$; whereas the mix containing a plasticizer, the residual changed to $(27 \%)$. At a temperature of $\left(600{ }^{\circ} \mathrm{C}\right)$ the residual proportions ranged between $(12 \%-35 \%)$; the mix containing retarding and water reducing admixture maintained the highest proportion $(35 \%)$ compared to the reference mix; whereas the least proportion $(12 \%)$ is maintained by the mix containing plasticizer.

The elastic modulus is related to its sensitivity of the aggregate stiffness more than to the cement paste stiffness [8]. However; there are - in general - several factors affecting the concrete elastic modulus exposed to high temperatures. These factors are [9]:

1- Strength of concrete.

2- Type of aggregate and its elastic properties.

3- Water-cement ratio.

4- Type of cement.

5- Sustained stresses.

On top of that, different types of additives may be taken as one of the factors affecting the elastic modulus.

\section{4. Ultimate Strain:}

Figure (4) shows variation of ultimate strain with high temperature for concrete mixes at the age of (28) days. It can be found that strain increases gradually with increasing temperature for all mixes. 
Table (4) show the percentage increases in ultimate strain for mixes having different type of additives for temperatures $(400,600){ }^{\circ} \mathrm{C}$. It can be concluded that the effect of high temperatures on ultimate strain varied and depends on type of additives.

Table (4): Percentage Increases in Ultimate Strain

\begin{tabular}{|l|l|l|l|l|l|l|}
\hline $\begin{array}{l}\text { Temp } \\
\text { Typd }\end{array}$ & $\begin{array}{l}\text { Reference } \\
\text { Concrete }\end{array}$ & $\begin{array}{l}\text { Super } \\
\text { plasticizer }\end{array}$ & Plasticizer & $\begin{array}{l}\text { Retarding \& } \\
\text { water reducing }\end{array}$ & $\begin{array}{l}\text { Accelerating } \\
\text { admixture }\end{array}$ & $\begin{array}{l}\text { Air entraining } \\
\text { admixture }\end{array}$ \\
\hline $400 \mathrm{C}^{\circ}$ & 178 & 155 & 188 & 195 & 146 & 136 \\
\hline $600 \mathrm{C}^{\circ}$ & 212 & 394 & 507 & 248 & 180 & 198 \\
\hline
\end{tabular}

No significant effect of additives on ultimate strain at a temperature of $\left(200{ }^{\circ} \mathrm{C}\right)$. While at $\left(400{ }^{\circ} \mathrm{C}\right)$ the increase in ultimate strain reduced from that of reference mix for the additive, air entraining, accelerator and superplasticizer, while the others having small effect. The increase in ultimate strain relative to the reference mix is obvious at $\left(600{ }^{\circ} \mathrm{C}\right)$ in the two additives (superplasticizer and plasticizer), so that increase in ultimate strain reached (394\%, $507 \%$ ) respectively.

\subsection{Compressive Stress-Strain Relations:}

The compressive stress-strain readings were presented in table (6) for all concrete mixes at the age of (28) days and for different temperature levels, each value was an average of three tested specimens.

The compressive stress-strain relations are represented for each mix and different temperatures by a suggested empirical formula, the data analyzed, using the statistical analysis program (SPSS 11.5). The general form of the empirical formula is given as in table (5), show the coefficient of equation (1) for the additives used:

$$
\sigma=\mathrm{X}_{1} * \varepsilon^{\mathrm{X} 2}+\mathrm{X}_{3} * \mathrm{~T}^{\mathrm{X} 4}+\mathrm{X}_{5} * \varepsilon+\mathrm{X}_{6} * \mathrm{~T}
$$

Table (5): The Coefficient Of Equation (1) For Concrete Mixes Used

\begin{tabular}{|c|c|c|c|c|c|c|}
\hline Additives & $\begin{array}{c}\text { Reference } \\
\text { Concrete }\end{array}$ & $\begin{array}{c}\text { Super } \\
\text { Plasticizer }\end{array}$ & Plasticizer & $\begin{array}{c}\text { Retarding \& } \\
\text { water } \\
\text { reducing }\end{array}$ & Accelerator & $\begin{array}{c}\text { Air } \\
\text { Entraining }\end{array}$ \\
\hline $\mathrm{X}_{1}$ & 25.857 & 65.8800 & 55.7800 & 215.3850 & 17.8350 & 23.028 \\
\hline $\mathrm{X}_{2}$ & 0.4795 & 0.6850 & 0.5865 & 0.9127 & 0.4244 & 0.4167 \\
\hline $\mathrm{X}_{3}$ & -0.0889 & -0.0905 & 3.9220 & 0.0930 & -.0888 & -0.0849 \\
\hline $\mathrm{X}_{4}$ & -5.7540 & -5.7699 & 0.9950 & -5.7620 & -5.7500 & -5.7530 \\
\hline $\mathrm{X}_{5}$ & -4.9600 & -27.2960 & -14.0900 & -176.6560 & -2.7700 & -3.6960 \\
\hline $\mathrm{X}_{6}$ & -0.0265 & -0.0567 & -3.8700 & -.0458 & -0.0213 & -.0242 \\
\hline $\mathrm{R}^{2}$ & 0.9130 & 0.931 & 0.9600 & 0.942 & 0.9586 & 0.9690 \\
\hline
\end{tabular}

To study the effect of the additives used in this research work, the compressive stress - strain curves are presented using the experimental data and the numerical equations (1), and table (5) for temperature $(20,200,400,600) \mathrm{C}^{\circ}$ as shown in figures ( 5 To 10 ). 
Table (6): Compressive Stress-Strain Readings.

\begin{tabular}{|c|c|c|c|c|c|c|c|c|}
\hline \multirow{2}{*}{$\begin{array}{c}\text { Concrete } \\
\text { Type }\end{array}$} & \multicolumn{2}{|c|}{$(20)^{\circ} \mathrm{C}$} & \multicolumn{2}{|c|}{$(200){ }^{\circ} \mathrm{C}$} & \multicolumn{2}{|c|}{$(400){ }^{\circ} \mathrm{C}$} & \multicolumn{2}{|c|}{$(600)^{\circ} \mathrm{C}$} \\
\hline & $\begin{array}{l}\text { Stress } \\
(\mathrm{MPa})\end{array}$ & $\begin{array}{c}\text { Strain } \\
\left(\mathrm{m} / \mathrm{m} \times 10^{-3}\right)\end{array}$ & $\begin{array}{l}\text { Stress } \\
(\mathrm{MPa})\end{array}$ & $\begin{array}{c}\text { Strain } \\
\left(\mathrm{m} / \mathrm{m} \times 10^{-3}\right)\end{array}$ & $\begin{array}{l}\text { Stress } \\
(\mathrm{MPa})\end{array}$ & $\begin{array}{c}\text { Strain } \\
\left(\mathrm{m} / \mathrm{m} \times 10^{-3}\right)\end{array}$ & $\begin{array}{l}\text { Stress } \\
(\mathrm{MPa})\end{array}$ & $\begin{array}{c}\text { Strain } \\
\left(\mathrm{m} / \mathrm{m} \times 10^{-3}\right)\end{array}$ \\
\hline \multirow{6}{*}{$\begin{array}{l}\text { Reference } \\
\text { Concrete }\end{array}$} & 11.51 & 0.40 & 3.32 & 0.17 & 2.50 & 0.11 & 4.50 & 0.54 \\
\hline & 16.70 & 0.73 & 10.23 & 0.58 & 5.50 & 0.46 & 7.30 & 1.31 \\
\hline & 20.36 & 1.15 & 17.36 & 1.38 & 11.00 & 1.40 & 9.00 & 2.25 \\
\hline & 22.65 & 1.42 & 21.20 & 2.03 & 18.68 & 3.10 & 10.85 & 3.76 \\
\hline & 26.80 & 2.30 & 24.50 & 2.69 & 22.80 & 4.57 & 12.15 & 5.67 \\
\hline & 30.04 & 3.20 & 28.40 & 3.70 & 24.90 & 5.70 & 12.60 & 6.80 \\
\hline \multirow{6}{*}{ Super plasticizer } & 8.00 & 0.16 & 9.50 & 0.33 & 8.34 & 0.58 & 6.25 & 0.72 \\
\hline & 12.60 & 0.26 & 18.00 & 0.61 & 15.40 & 0.98 & 10.00 & 1.20 \\
\hline & 20.40 & 0.40 & 25.60 & 0.84 & 22.20 & 1.45 & 12.50 & 1.95 \\
\hline & 32.10 & 0.82 & 32.56 & 1.17 & 28.90 & 2.00 & 15.35 & 3.77 \\
\hline & 48.35 & 1.66 & 41.70 & 1.77 & 34.40 & 2.63 & 16.47 & 6.95 \\
\hline & 55.78 & 2.40 & 47.80 & 2.62 & 38.34 & 3.72 & 17.24 & 9.49 \\
\hline \multirow{6}{*}{ Plasticizer } & 15.35 & 0.19 & 12.21 & 036 & 6.00 & 0.56 & 10.00 & 1.76 \\
\hline & 23.75 & 0.41 & 16.63 & 0.53 & 12.60 & 1.06 & 17.30 & 3.38 \\
\hline & 33.45 & 0.69 & 23.00 & 0.73 & 20.20 & 1.63 & 21.60 & 5.31 \\
\hline & 44.80 & 0.11 & 29.20 & 1.00 & 28.40 & 2.45 & 23.60 & 7.17 \\
\hline & 55.10 & 1.85 & 42.23 & 1.51 & 34.80 & 3.28 & 25.22 & 9.46 \\
\hline & 58.62 & 2.25 & 54.90 & 2.48 & 38.84 & 4.22 & 26.29 & 11.43 \\
\hline \multirow{6}{*}{$\begin{array}{c}\text { Retarding and } \\
\text { Water Reducing }\end{array}$} & 7.56 & 0.11 & 10.64 & 0.36 & 15.00 & 0.65 & 10.80 & 0.72 \\
\hline & 15.00 & 0.30 & 18.36 & 0.58 & 22.00 & 1.00 & 17.30 & 1.45 \\
\hline & 20.93 & 0.50 & 23.12 & 0.72 & 28.00 & 1.40 & 20.90 & 2.33 \\
\hline & 31.00 & 0.77 & 28.60 & 0.90 & 35.00 & 2.00 & 22.80 & 3.13 \\
\hline & 41.85 & 1.22 & 38.19 & 1.36 & 42.00 & 2.80 & 24.45 & 4.17 \\
\hline & 51.20 & 2.05 & 47.00 & 2.18 & 45.00 & 4.00 & 25.77 & 5.06 \\
\hline \multirow{9}{*}{ Accelerator } & 5.00 & 0.10 & 4.90 & 0.30 & 0.94 & 0.10 & 3.00 & 0.86 \\
\hline & 8.00 & 0.30 & 7.90 & 0.57 & 5.32 & 0.60 & 5.40 & 1.72 \\
\hline & 10.00 & 0.48 & 10.00 & 0.87 & 8.00 & 1.45 & 6.70 & 2.51 \\
\hline & 13.00 & 0.84 & 12.40 & 1.31 & 9.00 & 2.14 & 7.30 & 3.43 \\
\hline & 16.00 & 1.46 & 15.40 & 2.11 & 9.75 & 2.78 & 7.70 & 4.62 \\
\hline & 19.40 & 2.56 & 17.10 & 2.76 & 10.88 & 3.95 & 7.80 & 5.70 \\
\hline & 20.50 & 3.22 & 17.90 & 3.42 & 11.65 & 4.94 & 8.00 & 6.94 \\
\hline & 21.00 & 3.86 & 18.70 & 4.49 & 11.98 & 6.00 & 8.10 & 8.05 \\
\hline & 21.20 & 5.00 & 19.10 & 5.60 & 12.50 & 7.30 & 8.22 & 9.00 \\
\hline \multirow{7}{*}{ Air Entraining } & 11.36 & 0.46 & 8.23 & 0.35 & 6.82 & 0.58 & 3.96 & 0.69 \\
\hline & 16.64 & 0.73 & 13.13 & 0.71 & 10.62 & 1.03 & 7.25 & 1.35 \\
\hline & 19.77 & 0.93 & 15.68 & 1.06 & 13.45 & 1.60 & 8.99 & 2.01 \\
\hline & 22.50 & 1.47 & 17.64 & 1.64 & 14.96 & 2.44 & 9.98 & 2.77 \\
\hline & 24.87 & 2.35 & 18.72 & 2.33 & 16.03 & 3.26 & 10.73 & 3.64 \\
\hline & 26.18 & 3.10 & 19.35 & 2.93 & 16.57 & 4.00 & 11.88 & 5.16 \\
\hline & 26.92 & 3.48 & 20.19 & 3.59 & 16.96 & 4.73 & 13.19 & 6.95 \\
\hline
\end{tabular}

$*$ The results of table(5) are the average of three tested specimens for each. 


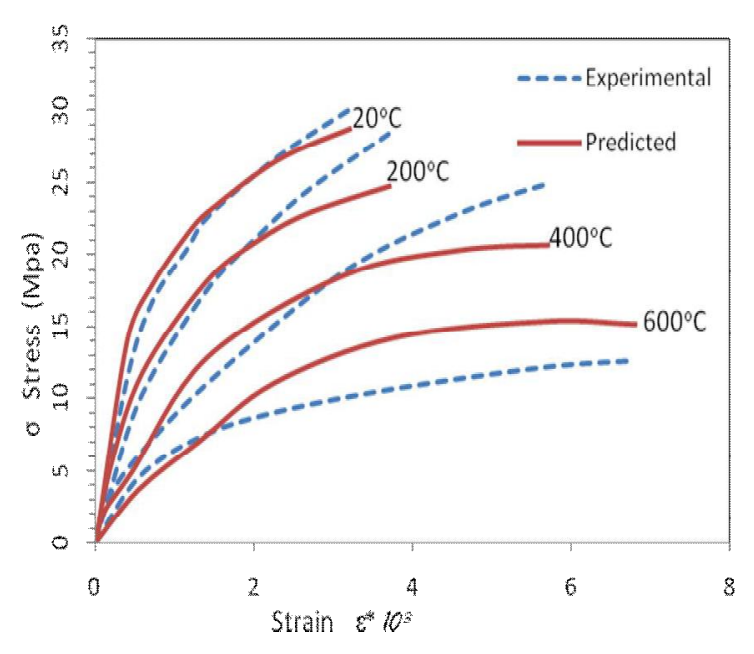

Figure (5): The stress-strain relationships for reference mix

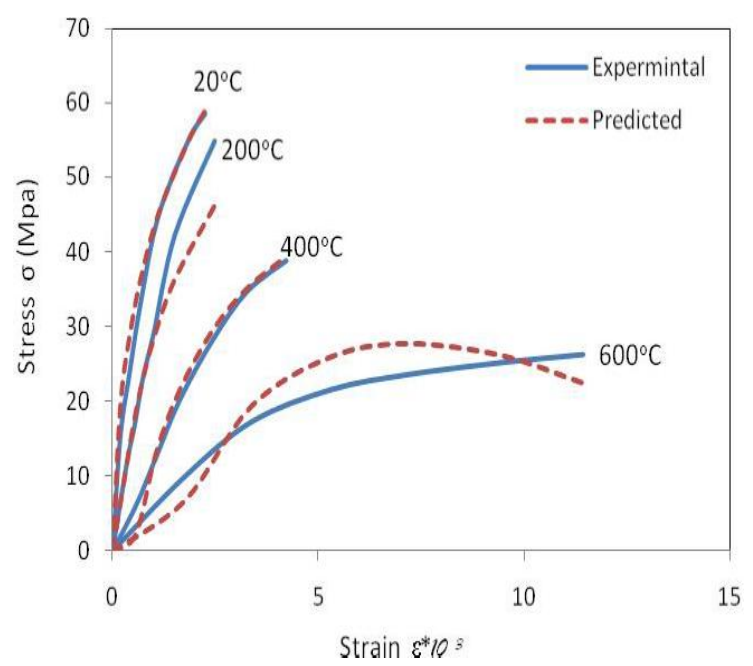

Figure (7): The stress-strain relationships for the mix containing plasticizer

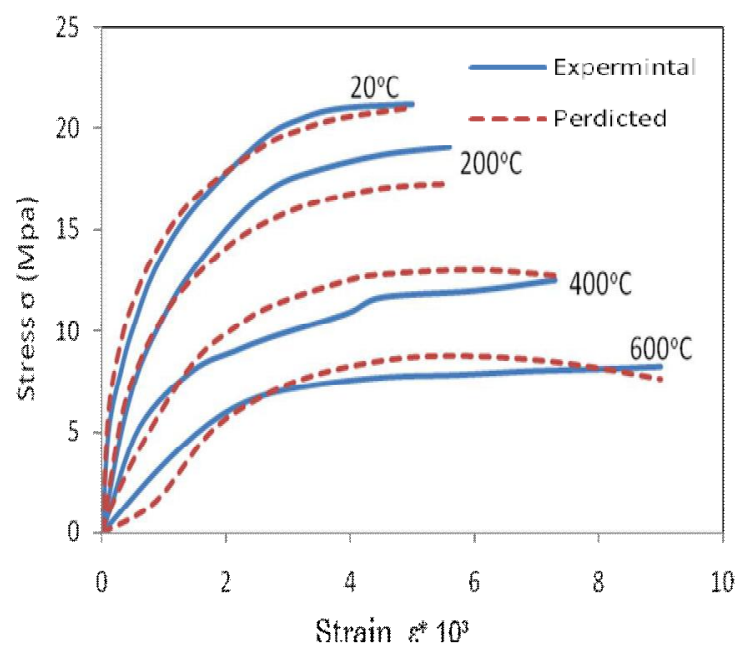

Figure (9): The stress-strain relationships for the mix containing accelerating admixture

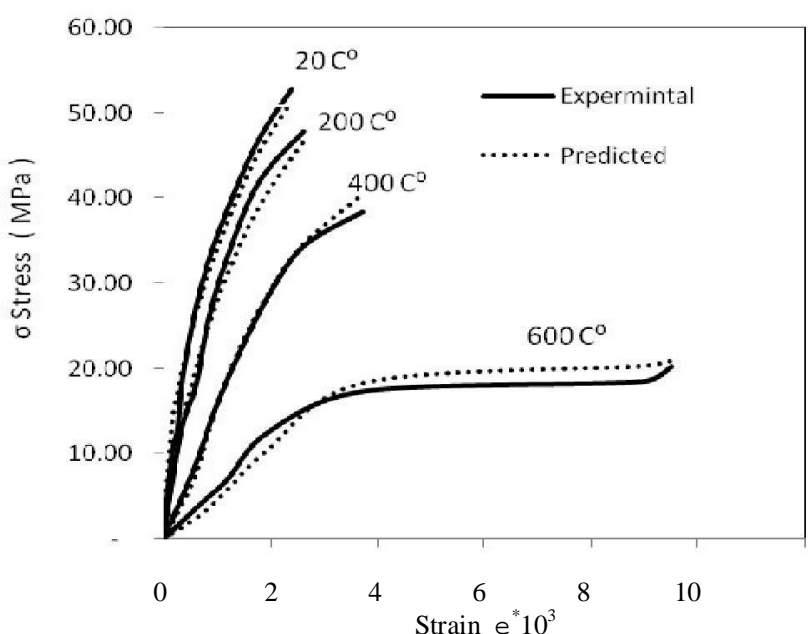

Figure (6): The Stress - Strain relation for the Mix containing Super Plasticizer

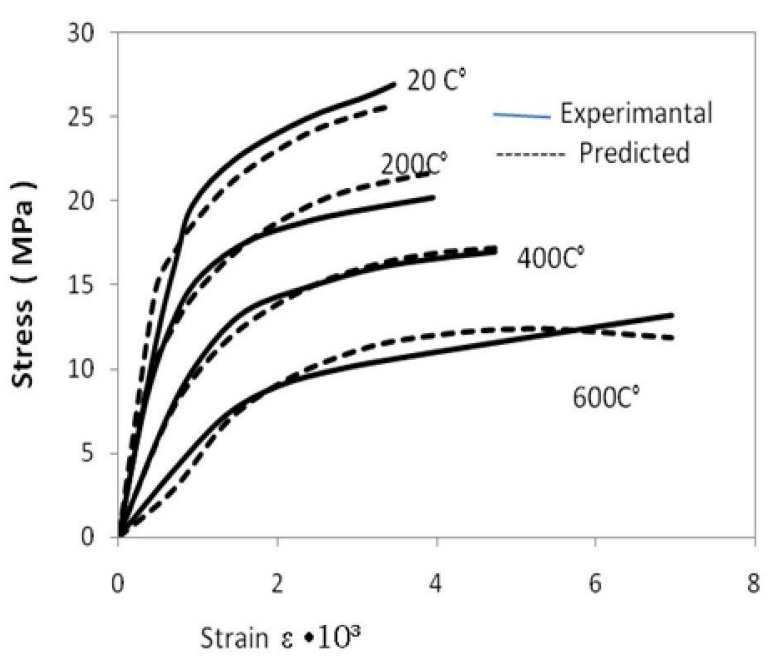

Fig. ( 8 ) : Stress - Strain relation

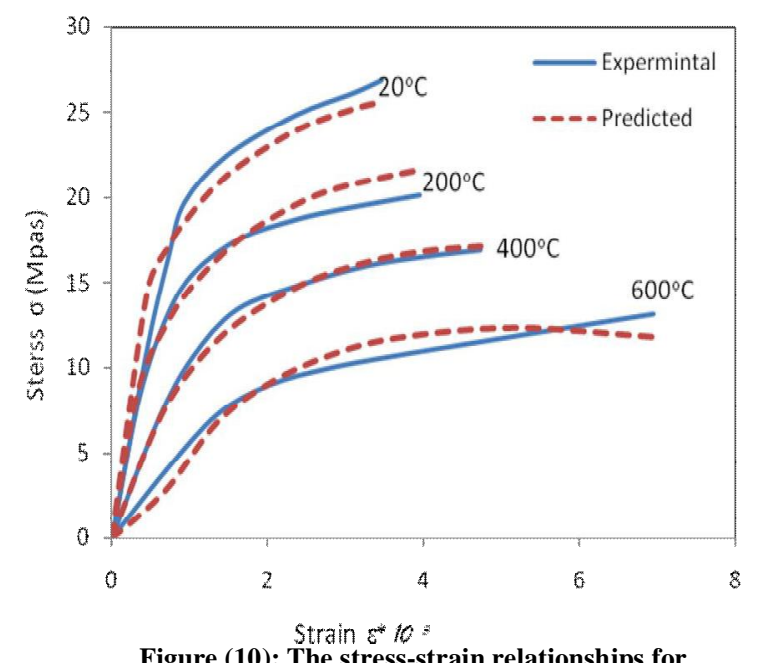
the mix containing air entraining admixture 
The trend of the compressive stress-strain relation for concrete containing accelerating admixture shows that this type of mix is more ductile than the reference concrete; The other types of mixes show a brittle concrete. All mixes become more ductile at higher temperature.

It is worth to mentioning that there are several factors affecting the behavior of (stress-strain) relationship including [9, 10]:

1- Aggregate-cement ratio.

2- Curing conditions.

3- Binder material type.

4- Aggregate type.

The type of additive may be added to the above factors.

\section{CONCLUSIONS}

1- The existence of concrete additive in the concrete mix exposed to high temperatures resulting variable changes in compressive strength, splitting tensile strength, elastic modulus and ultimate strain, compared to the reference mix. These changes -in general-varied from one additive to another for different temperatures; however it was limited at $\left(200{ }^{\circ} \mathrm{C}\right)$ and soon became evident at $(400,600)^{\circ} \mathrm{C}$.

2- The mix containing a plasticizer maintained the higher residual proportion of the compressive strength at a temperature of $\left(200{ }^{\circ} \mathrm{C}\right)$; while the mix containing the retarding and water reducing additive maintained the highest residual compressive strength at temperatures of $(400,600){ }^{\circ} \mathrm{C}$.

3- The mix containing superplasticizer gives the highest residual splitting tensile strength at a temperature of $\left(200{ }^{\circ} \mathrm{C}\right)$. At temperature $\left(400{ }^{\circ} \mathrm{C}\right)$ the highest value is obtained for mix containing plasticizer, and at $\left(600{ }^{\circ} \mathrm{C}\right)$ it is found that the mix containing an accelerating additive is maintained the highest percentage of this strength.

4- The highest residual proportion of elastic modulus is obtained by the mix containing air entraining additive at a temperature of $\left(200{ }^{\circ} \mathrm{C}\right)$; While at $(400,600){ }^{\circ} \mathrm{C}$ the highest value is obtained by the mix containing retarding and water reducing additive.

5- The mix containing an accelerating additive gave the highest proportion of an increase in the ultimate strain at a temperature of $\left(200{ }^{\circ} \mathrm{C}\right)$; whereas the mix containing retarding and water reducing additive gave the highest increase at a temperature of $\left(400{ }^{\circ} \mathrm{C}\right)$. The mix containing plasticizer gives the highest increase at a temperature of $\left(600{ }^{\circ} \mathrm{C}\right)$.

6- It can be concluded that the effect of additives may be considered as one of the factors affecting the heat-treatment of concrete with other factors.

\section{REFERENCES}

[1] E. Tolentino, F. Lameiras, A. Gomes, C. Silva and W. Vasconcelos, "Effects of High Temperature on the Residual Performance of Portland Cement Concretes", Materials Research, 5 (2002), p. 1 - 11.

[2] N. Yüzer, F. Aköz and L. Öztürk, "Compressive Strength - Color Change Relation in Mortars at High Temperature", Cement and Concrete Research, (2004), p. 1 - 5. 
[3] A. Savva, P. Manita and K. K. Sideris, "Influence of Elevated Temperatures on the Mechanical Properties of Blended Cement Concretes Prepared with Limestone and Siliceous Aggregates", Cement and Concrete Research, 27 (2005), p. 239 - 248.

[4] A. M. Neville, "Properties of Concrete", Pitman Publishing Ltd, London,(1975).

[5] I. Janotka, and L. Bágel, "Pore Structures, Permeabilities, and Compressive Strengths of Concrete at Temperatures up to $800^{\circ}$ C", ACI Materials Journal, 99 (2002), p. 196 200.

[6] G. T. G. Mohamedbhai, "Effect of Exposure Time and Rates of Heating and Cooling on Residual Strength of Heated Concrete", Magazine of Concrete Research, 38 (1986), p. $151-158$.

[7] ACI Committee 318, "Building Code Requirements for Structural Concrete ACI", American Concrete Institute, (2002).

[8] R. Ravindrarajah, R. Lopez, and H. Reslan, , "Effect of Elevated Temperature on the Properties of High Strength Concrete Containing Cement Supplementary Materials", Center of Built Infrastructure Research, University of Technology, Sydney, Australia, (2002), p. $1-9$.

[9] U. Schneider, "Concrete at High Temperature", Fire Safety Journal, 13 (1988), p. 55 56.

[10] I. Janotka, and T. Nürnbergerova,, "Effect of Temperature on Structural Quality of High-Strength Concrete with Silica Fume", Institute of Construction and Architecture, Slovak Academy of Sciences, Bratislava, Slovak Republic, (2003), p. $1-8$. 